\title{
The Global Green Bond Market in the Face of the COVID-19 Pandemic
}

http://doi.org/10.21272/fmir.5(1).50-60.2021

Greta Keliuotytè-Staniulènienė, ORCID: https://orcid.org/0000-0001-8089-8866

Associate Professor, Doctor of economics, Vilnius University, Faculty of Economics and Business Administration, Finance department, Vilnius, Lithuania

\section{Kamilè Daunaravičiūtè}

Master of Finance and Banking, Vilnius University, Faculty of Economics and Business Administration, Finance department, Vilnius, Lithuania

\begin{abstract}
This paper summarizes the relevant researches in the area of the green bond market within the perspective of the performance of the global green bond market in the face of the COVID-19 pandemic. Despite the rapid expansion of the green bond market during the last decade, this market has also experienced the consequences of the COVID-19 pandemic. The researches on the effect of COVID-19 and its induced crisis on the green bond markets are still fragmentary; therefore, the main purpose of this research is to evaluate the impact of the COVID-19 pandemic on the global green bond market. To reach the purpose, the methods of literature analysis, and correlation-regression analysis are used. In the first section of the paper, the research problem is presented; in the second part the analysis of academic literature is conducted; in the third part the design of the research is described, and in the fourth part the results of the assessment of the impact of COVID-19 pandemic on the global green bond market are discussed. The results of the research revealed that the spread of the COVID-19 pandemic appeared to have a negative impact on the performance of the S\&P Green Bond Index. The market reaction to deaths caused by COVID-19 infection proved to be stronger than the reaction to confirmed cases of COVID-19 infection. However, after a sufficiently significant negative shift, which was observed in the first quarter of 2020, the S\&P Green Bond Index regained its upward trend, which continued for the rest of the year.
\end{abstract}

Keywords: green bonds; COVID-19 pandemic; market value index; market volatility.

JEL Classification: G10; Q56; H74.

Cite as: Keliuotytė-Staniulènienè, G., Daunaravičiūtè, K. (2021). The Global Green Bond Market in the Face of the COVID-19 Pandemic. Financial Markets, Institutions and Risks, 5(1), 5060. http://doi.org/10.21272/fmir.5(1).50-60.2021

Received: 26 January 2021

Accepted: 3 March 2021

Published: 30 March 2021

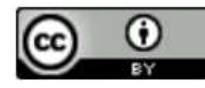

Copyright: (C) 2021 by the authors. Licensee Sumy State University, Ukraine. This article is an open access article distributed under the terms and conditions of the Creative Commons Attribution (CC BY) license (https://creativecommons.org/licenses/by/4.0/)

\section{Introduction}

Since the first issuance in the year 2007, the green bond market has attracted great interest from the market participants and has demonstrated a rapid expansion: from annual issuance of 30 billion U.S. dollars in the year 2013 (Tukhanen \& Vulturius, 2020) to a new annual record of 270 billion U.S. dollars in the year 2020 (Sustainable Bond Insight, 2021). However, it is important to mention that although the significant development of the green bond markets is observed in advanced economies, the green bond market in lower and middle-income countries is still in the embryonic state (Otec Ntsama et al., 2021). Moreover, despite the demonstrated tremendous growth, the green bond market still remains small in comparison with the fixedincome market (Liaw, 2020).

Despite the outstanding success of the green bond market during the last decade, this market has also inevitably confronted with the consequences of the COVID-19 infection and pandemic-induced downturn. Whereas there 
are little researches on the effect of COVID-19 and its induced crisis on the green bond markets, the main purpose of this paper is to evaluate the impact of the COVID-19 pandemic on the global green bond market. Seeking to achieve the main purpose, after the analysis of relevant academic literature, we use the method of correlation-regression analysis in order to quantitatively assess the effect that COVID-19 had made on the global green bond market. For our research, as a dependent variable the S\&P Green Bond Index was selected, and as independent variables the COVID-19 related measures were used.

The rest of the paper is structured as follows: (i) in Section 1 the analysis of the academic literature is conducted, (ii) in Section 2 the logics and design of the research are described, (iv) in Section 3 the results of the assessment of the impact of the COVID-19 pandemic on the global green bond market is discussed; and finally, (v) the conclusions and directions for future research are presented.

\section{Literature review}

Climate change and deterioration of the environment, both induced by fast and unsustainable economic growth, have been threatening the world for decades. International institutions make great efforts in order to ensure sustainable and resource-efficient economic growth (for example, Paris Agreement (United Nations Framework Convention of Climate Change) or A European Green Deal (European Commission)). Funding of such efforts has become an essential issue of climate negotiations (Flaherty et al., 2017). Being one of the most important drivers of economic growth, the financial sector has also been seeking sustainable and climateneutral decisions. Green bonds are one of the most important innovations of sustainable finance (Maltais \& Nykvist, 2020), also a crucial tool for raising funds necessary to reach the climate targets (Tukhanen \& Vulturius, 2020) Moreover, empirical evidence allows to state that the green bonds not only contribute to a low-carbon transition, but also positively affects economic growth (Glomsrod \& Wei, 2018).

From a perspective of financial market participants, it could be stated that the green bonds provide benefits for both issuers and investors. On the one hand, the issuers can: (i) assess a broader range of investors, i.e. reach better visibility; (ii) get a better price and more favorable terms, (iii) facilitate more engagement with the investor; (iv) improve their internal processes; (v) enhance their reputation; and even (vi) develop new business lines and commercial opportunities (Harrison et al., 2020; KPMG, 2015; Baker, 2018; Zhou \& Cui, 2019; Choi et al.; 2020; Ehlers \& Packer, 2017; Zerbib; 2019; Kapraun \& Scheins; 2019). As it is stated by Zhou \& Cui (2019), participation in the green bond market can positively affect companies' stock price, profitability, operational performance, and innovation capacity. However, Liaw (2020), after conducting a survey of academic literature, indicates that some researches on green bond premium found that the yield of the green bond is lower than the yield of a conventional bond, while other studies did not support the existence of green bond yield discount (greenium or green premium). Moreover, the green bonds are associated not only with financial, but also with environmental risks (Bigger, 2017).

On the other hand, the green bond market allows investors to: (i) diversify their investments; (ii) get involved in environmental-friendly investment projects; (iii) support their investment decisions by additional (sustainability-related) information about issuers; (iv) increase exposure in less volatile instruments; and (v) achieve the desired risk-return ratio (Alonso-Conde \& Rojo-Suarez, 2020; Deschryver \& de Mariz, 2020; Ng, 2018; Lebelle, 2020; Wanke, 2017; King, 2017; Hachenberg \& Schiereck, 2018; Jansson \& Biel, 2014).

The rapid growth of the green bond market raises not only practical but also academic discussion. In the academic literature, authors analyze the green bond market from different perspectives. The development of the green bond market and interrelation of finance and green projects were analyzed by Baker et al. (2018), Ehlers \& Packer (2017), Upbin et al. (2014), Preclaw \& Bakshi (2015), Ludvigsen (2015), Hjort (2016), Grene (2015) and others. The expansion of the green bond market and its dependence on macroeconomic conditions were analyzed by Cochu (2016) and Jun et al. (2016). Tolliver (2020), Gilchrist et al. (2021), Banga (2019) analyze the volume of green bond issuances and the main drivers of green bond market growth. Liaw (2020), Cheong \& Choi (2020), Flammer (2018), Karpf \& Mandel (2017), Packer \& Ehlers (2017), Reboredo (2018), Zerbib (2018), and others discussed the issues of green bond pricing and green bond premiums. Although the theoretical and practical issues of the bond markets are analyzed in significant number of scientific researches, the market of green bonds is relatively new, therefore, there is still a lack of a comprehensive green bond market analysis.

Despite the considerable success of the last decade, as well as other financial markets, the green bond market has been affected by the COVID-19 pandemic and its induced economic and social constraints. Deteriorating expectations and growing uncertainty in the markets inevitably affected investors' decisions. As it is stated by 
Anh Tu et al. (2020), financial stability is one of the most important factors of the green bond market. Thus, the period of financial uncertainty caused by the COVID-19 pandemic, could have an impact on the green bond market, at least in a short term.

In the first half of the year 2020, the green bond market experienced a rapid decrease which was related to the impact of the spread of COVID-19 pandemic on financial markets and the economy as a whole (Oxford Analytica, 2020). It is stated that the pandemic affected the green bond market in at least three ways: (i) issuance of green bonds decreased sharply in March 2020 and was the lowest since the year 2015; (ii) as a consequence of bond yield volatility, decrease in risk assets and market liquidity, widened corporate spreads andthe negative effect of green bond mutual funds and ETFs was observed in March 2020; (iii) however, at the same time, the green bond market experienced a positive cash flow and increase of total assets (Sustainable Investing, 2020).

Despite the sudden and negative impact of the COVID-19 pandemic, the green bond market recovered during the second half of the year 2020 and is about to reach a new annual record of 350 billion U.S. dollars in 2021 (Sustainable Bond Insight, 2021).

Despite the discussed impact of the COVID-19 pandemic on the green bond market, the scientific analysis of this impact is still very fragmentary. For example, Xing Yi et al. (2021) have analyzed the effect of the pandemic on China's green bond market and found out that in the face of the COVID-19 pandemic, the cumulative abnormal return of green bonds increased significantly. However, after the first relieve of the pandemic, the cumulative abnormal return of green bonds dropped rapidly (Xing Yi et al., 2021). Otec Ntsama et al. (2021) noted that the trend for green bonds remains of large and diverse growth despite the spread of the COVID-19 pandemic.

Incomparably more researches investigated the impact of the COVID-19 pandemic on stock markets (for example, Quing et al. 2020; Zhang et al. 2020; Kanapickiene et al., 2020; Sansa 2020; Albulescu 2020; Gormsen \& Koijen 2020; Schoenfeld 2020 and others) - the results of which revealed a sudden negative effect on global and regional stock markets. Due to the interconnectedness of separate financial markets, assumptions about the impact on bond markets can be made. Interestingly, Park et al. (2020) conducted econometric analysis of the green bond market in the perspective of the relationship of green bond and stock market. The results of this research revealed that green bonds tend to exhibit asymmetrical volatility; however, their volatility is sensitive to positive shocks, which is not the case for other financial instruments. The authors also confirmed that "the green bond and equity markets have some volatility spillover effects but that neither responds significantly to negative shocks in the other market" (Park et al., 2020). Thus, it is important to analyze the reaction of the green bond market and to compare it with one of the stock market in the face of the COVID-19 pandemic.

\section{Research methodology}

Seeking to achieve the main purpose of this research, i.e. to assess the impact of the COVID-19 pandemic on the green bond market, the global green bond market is selected for further analysis. In order to get a broad picture of the global green bond market, S\&P Green Bond Index, tracking the global green bond market and including only the bonds whose proceeds are used to finance environmentally friendly projects (S\&P Dow Jones Indices, 2021), is analyzed. This index is selected as the broad market value-weighted index, covering green-labeled bonds from around the world, issued by multilateral, government, and corporate issuers (S\&P Dow Jones Indices, 2021).

The research is organized in two steps. In the first step, the long-term and short-term trends of S\&P Green Bond Index (from the perspective of market value and yield to maturity) are analyzed (Subsection 3.1). In the second step, the effect of COVID-19 on the dynamics of S\&P Green Bond Index is being assessed (Subsection 3.2). The second step itself consists of two phases: (i) assessment of the impact of the COVID-19 pandemic on the global green bond market on the basis of S\&P Green Bond Index market value and yield to maturity daily data; and (ii) assessment of the impact of the spread of the COVID-19 pandemic on the volatility of S\&P Green Bond Index on the basis of monthly data.

Seeking to achieve the main purpose of the paper, the following hypotheses are formulated: 
Hypothesis 1: the spread of the COVID-19 pandemic has negatively affected the global green bond market, i.e. statistically significant negative (positive) impact on market value (yield to maturity) of S\&P Green Bond Index can be observed.

Hypothesis 2: the spread of the COVID-19 pandemic has increased the volatility of S\&P Green Bond Index, i.e. statistically significant positive impact can be observed.

Both hypotheses are tested using the method of correlation-regression analysis. Linear (bivariate) regression models for each pair of dependent and independent variables are constructed. Statistical characteristics of these models (t-value, $\mathrm{p}$ statistics) allow confirming or rejecting the hypotheses.

In order to test Hypothesis 1, the dependent variable the S\&P Green Bond Index (market value and yield to maturity) is selected; as independent variables two COVI9-19 related measures are chosen: (i) percentage growth rate of COVID-19 cases confirmed per day globally; (ii) percentage growth of deaths caused by COVID-19 reported per day globally. Index data is retrieved from S\&P Dow Jones Indices official database, the growth rates of COVID-19 cases and deaths are calculated by authors using the data provided in Our World in Data Coronavirus Pandemic Statistics (Coronavirus Pandemic, 2021) (daily data). Subject to data availability, the sample covers the period from $22^{\text {nd }}$ January 2020 to $8^{\text {th }}$ February 2021 and includes 273 observations.

In order to test Hypothesis 2, the monthly volatility of the S\&P Green Bond Index market value is selected as dependent, and the percentage growth rates of COVID-19 cases and deaths per month are selected as independent variables. As it is the most common, volatility is measured by the standard deviation of the S\&P Green Bond Index market value (percentage, per month). Using monthly data, the sample covers the period from January 2020 to December 2020 and includes 12 observations.

The summary of descriptive statistics of dependent and independent variables for the models of COVID19 impact on the global bond market is provided in Table 1.

Table 1. Descriptive statistics of selected variables

\begin{tabular}{|c|c|c|c|c|c|c|c|}
\hline & \multicolumn{4}{|c|}{ Daily data based variables } & \multicolumn{3}{|c|}{ Monthly data based variables } \\
\hline & $\begin{array}{c}\text { S\&P Green Bond Index } \\
\text { (Market Value) }\end{array}$ & $\begin{array}{c}\text { S\&P } \\
\text { Green } \\
\text { Bond } \\
\text { Index } \\
\text { Yield to } \\
\text { Maturity }\end{array}$ & $\begin{array}{l}\text { Daily } \\
\text { growth of } \\
\text { COVID- } \\
19 \text { cases } \\
\end{array}$ & $\begin{array}{c}\text { Daily } \\
\text { growth of } \\
\text { deaths } \\
\text { from } \\
\text { COVID- } \\
19 \\
\end{array}$ & $\begin{array}{l}\text { S\&P Green Bond Index } \\
\text { Volatility }\end{array}$ & $\begin{array}{c}\text { Monthly } \\
\text { growth of } \\
\text { COVID-19 } \\
\text { cases }\end{array}$ & $\begin{array}{c}\text { Monthly } \\
\text { growth of } \\
\text { deaths from } \\
\text { COVID-19 }\end{array}$ \\
\hline Mean & 148.106 & 0.013 & 3.421 & 3.277 & 1.375 & 199.291 & 282.195 \\
\hline Median & 150.490 & 0.012 & 1.392 & 0.869 & 0.733 & 56.616 & 29.448 \\
\hline Maximum & 158.990 & 0.022 & 90.571 & 59.756 & 5.143 & 918.211 & 1412.305 \\
\hline Minimum & 133.140 & 0.009 & 0.294 & 0.178 & 0.443 & 23.282 & 17.909 \\
\hline Std. Dev. & 6.871 & 0.003 & 7.564 & 6.625 & 1.365 & 309.538 & 511.456 \\
\hline Skewness & -0.197 & 0.932 & 7.213 & 4.868 & 1.958 & 1.670 & 1.630 \\
\hline Kurtosis & 1.879 & 3.668 & 71.880 & 33.573 & 5.890 & 4.060 & 3.863 \\
\hline Jarque-Bera & 16.131 & 44.786 & 56336.170 & 11710.480 & 11.845 & 6.139 & 5.685 \\
\hline Probability & 0.000 & 0.000 & 0.000 & 0.000 & 0.003 & 0.046 & 0.058 \\
\hline Sum & 40580.960 & 3.456 & 933.903 & 894.530 & 16.506 & 2391.493 & 3386.336 \\
\hline $\begin{array}{l}\text { Sum Sq. } \\
\text { Dev. }\end{array}$ & 12887.860 & 0.002 & 15561.930 & 11937.660 & 20.502 & 1053953.000 & 2877459.000 \\
\hline Observations & 274.000 & 274.000 & 273.000 & 273.000 & 12.000 & 12.000 & 12.000 \\
\hline
\end{tabular}

Source: authors calculations on the basis of S\&P Dow Jones Indices official database and Our World in Data Coronavirus Pandemic data.

The dynamics of COVID-19 related variables (growth rates of COVID-19 cases and deaths) (Appendixes A and B) allows identifying two major peaks (periods of highest growth rates): (i) the second half of January 2020 - the first half of February 2020; and (ii) the second half of March 2020 - the first half of April 2020; the first of which coincides with the spread of COVID-19 in China and related regions and the second - with the global spillover of the infection. In addition, a slight increase in the growth rate of COVID-19 cases can be observed in December 2020.

Further, the main results of the research are presented. 


\section{Results and discussion}

In this section, the dynamics of the S\&P Green Bond Index is analyzed and the impact of the COVID-19 is evaluated.

3.1. Long and short-term trends of the global green bond market. As it is revealed in Figure 1, which shows the long-term dynamics of S\&P index market value, from the beginning of the year 2016 a sufficiently obvious positive trend was observed. This increase was accompanied by an increase in issuances and volumes in the green bond market, as it was discussed in Section 1. However, from the same figure, it can be assumed that starting with February 2020 the global green bond market experienced the largest drop during all investigated period, and the S\&P Green Bond Index lost more than 7 percent of its value during two weeks in March 2020.

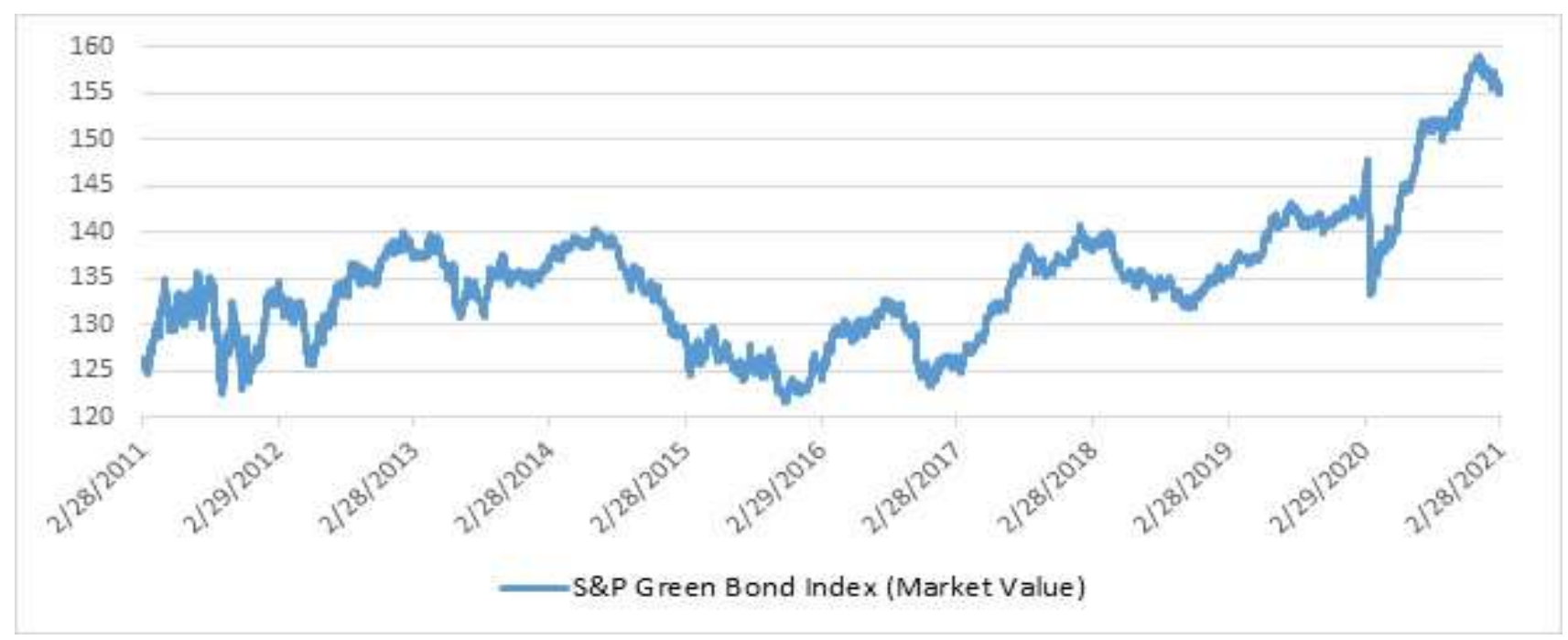

Figure 1. Long-term dynamics of S\&P Green Bond Index (Market Value) - 2011/02/28-2021-02/28

Source: compiled by authors on the basis of S\&P Dow Jones Indices official database data

Figure 2 (as well as Appendix C) allows indicating following trends of market value and yield to maturity of S\&P Green Market Index: (i) after a sufficiently significant negative shift in terms of the market value observed in the first quarter of 2020, the index regained its upward trend, which continued for the rest of the year; (ii) at the beginning of 2021 the index reversed to a moderate downward trend (Figure 2); (iii) yields to maturity rose sharply over the same period, reaching a record level of 2.15 percent in March 2020 (Appendix C).

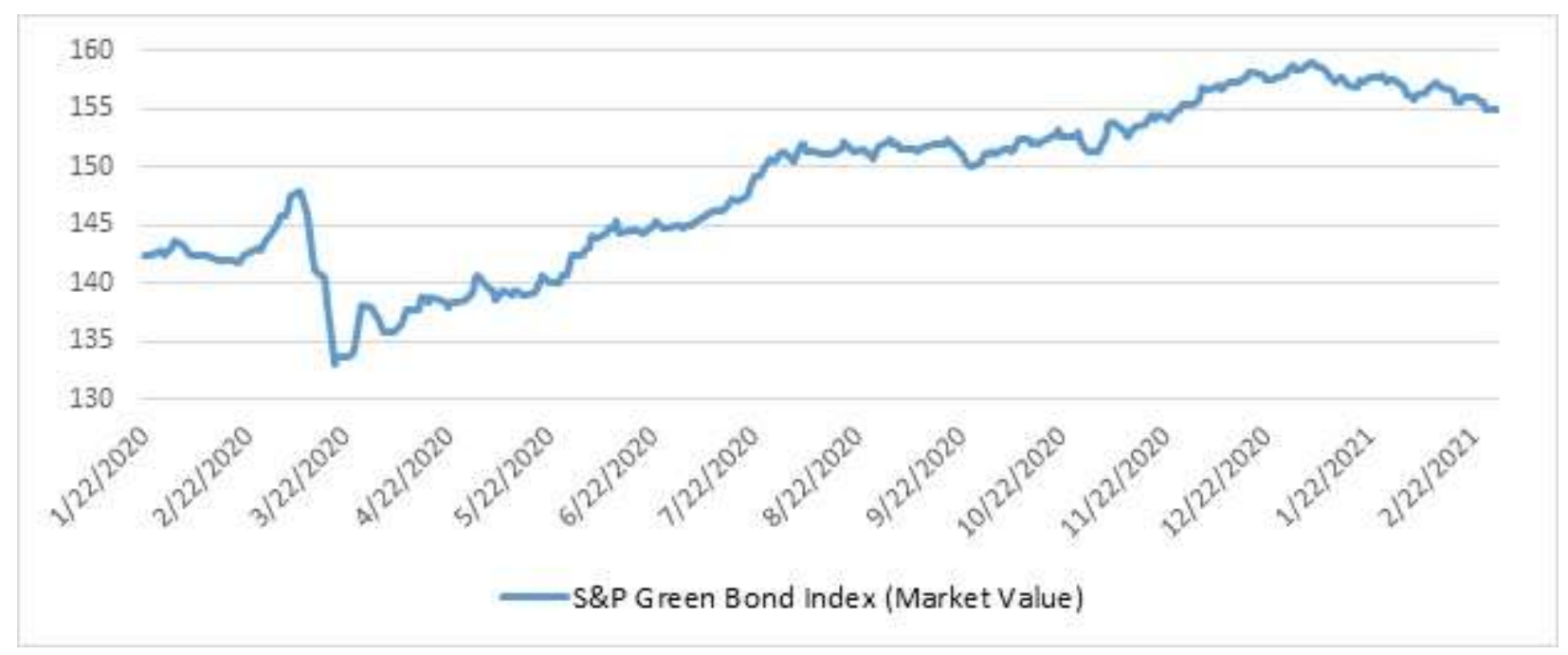

Figure 2. Short-term dynamics of S\&P Green Bond Index (Market Value) - 2020/01/22-2021-01/22

Source: compiled by authors on the basis of S\&P Dow Jones Indices official database data 
The results of the graphical analysis allow assuming sudden and sufficiently significant COVID-19 effect on the global green bond market, as was also noted by Xing Yi et al. (2021). Nevertheless, it is necessary to emphasize the short-term nature of this effect, as there are clear signs of market recovery after initial negative shock. Moreover, a positive trend in this market can be observed, as was also discussed by Otec Ntsama et al. (2021). Further research aims to evaluate the effect of the COVID-19 pandemic on the global green bond market quantitatively.

3.2. Assessment of the impact of the COVID-19 pandemic on the global green bond market. The results of the correlation analysis are presented in Table 2.

Table 2. Correlation between S\&P Green Bond Index (market value and yield to maturity) and COVID-19 variables

\begin{tabular}{|c|c|c|c|c|}
\hline Variables & Correlation & t-statistic & Probability & Observations \\
\hline \multicolumn{5}{|c|}{ S\&P Green Bond Index (Market Value) } \\
\hline Daily growth of COVID-19 cases & -0.342674 & -6.00467 & 0 & 273 \\
\hline Daily growth of deaths from COVID-19 & -0.435171 & -7.95671 & 0 & 273 \\
\hline \multicolumn{5}{|c|}{ S\&P Green Bond Index Yield to Maturity } \\
\hline Daily growth of COVID-19 cases & 0.35125 & 6.175823 & 0 & 273 \\
\hline Daily growth of deaths from COVID-19 & 0.457283 & 8.464696 & 0 & 273 \\
\hline \multicolumn{5}{|c|}{ S\&P Green Bond Index Volatility } \\
\hline Monthly growth of COVID-19 cases & 0.595856 & 2.346264 & 0.0409 & 12 \\
\hline Monthly growth of deaths from COVID-19 & 0.546685 & 2.064603 & 0.0659 & 12 \\
\hline
\end{tabular}

Source: authors calculations on the basis of S\&P Dow Jones Indices official database and Our World in Data Coronavirus Pandemic data.

On the basis of the results of Table 2 (correlation coefficients, t-statistics, and probabilities), it can be stated the following: (i) daily growth rates of COVID-19 cases and deaths are statistically significantly negatively (positively) related to market value (yield to maturity) of S\&P Green Bond Index (moderate or week relationship); (ii) monthly growth rate of COVID-19 cases is statistically significantly related to the volatility of S\&P Green Bond Index; (iii) relationship between S\&P Green Bond Index and death growth rate is stronger than the relationship with cases growth rate, i.e. the market is more responsive to the mortality rather than the increase of infection cases.

To get a better view of the impact of COVID-19 on the green bond market, linear (bivariate) regression models are constructed, the results of which are presented in Tables 3 and 4.

Table 3. Bivariate regression models of the impact of the COVID-19 pandemic on global green bond market (daily data)

\begin{tabular}{|c|c|c|c|c|c|c|c|}
\hline Variable & Constant & Coefficient & $\begin{array}{l}\text { Std. } \\
\text { Error }\end{array}$ & t-Statistic & Probability & R-squared & Observations \\
\hline \multicolumn{8}{|c|}{ S\&P Green Bond Index (Market Value) } \\
\hline $\begin{array}{l}\text { Daily growth of COVID-19 } \\
\text { cases }\end{array}$ & 149.192 & -0.311 & 0.052 & -6.005 & 0.000 & 0.117 & 273 \\
\hline $\begin{array}{l}\text { Daily growth of deaths from } \\
\text { COVID-19 }\end{array}$ & 149.606 & -0.452 & 0.057 & -7.957 & 0.000 & 0.189 & 273 \\
\hline \multicolumn{8}{|c|}{ S\&P Green Bond Index Yield to Maturity } \\
\hline $\begin{array}{l}\text { Daily growth of COVID-19 } \\
\text { cases }\end{array}$ & 0.012 & 0.000 & 0.000 & 6.176 & 0.000 & 0.123 & 273 \\
\hline $\begin{array}{l}\text { Daily growth of deaths from } \\
\text { COVID-19 }\end{array}$ & 0.012 & 0.000 & 0.000 & 8.465 & 0.000 & 0.209 & 273 \\
\hline
\end{tabular}

Source: authors calculations on the basis of S\&P Dow Jones Indices official database and Our World in Data Coronavirus Pandemic data.

Table 4. Bivariate regression models of the impact of the COVID-19 pandemic on global green bond market (monthly data)

\begin{tabular}{|c|c|c|c|c|c|c|c|}
\hline Variable & Constant & Coefficient & $\begin{array}{l}\text { Std. } \\
\text { Error }\end{array}$ & t-Statistic & Probability & R-squared & Observations \\
\hline \multicolumn{8}{|c|}{ S\&P Green Bond Index Volatility } \\
\hline $\begin{array}{l}\text { Monthly growth of COVID-19 } \\
\text { cases }\end{array}$ & 0.852 & 0.003 & 0.001 & 2.346 & 0.041 & 0.355 & 12 \\
\hline $\begin{array}{l}\text { Monthly growth of deaths from } \\
\text { COVID-19 }\end{array}$ & 0.964 & 0.001 & 0.001 & 2.065 & 0.066 & 0.299 & 12 \\
\hline
\end{tabular}

Source: authors calculations on the basis of S\&P Dow Jones Indices official database and Our World in Data Coronavirus Pandemic data. 
In Phase 1 the impact of the COVID-19 pandemic is assessed using daily market value and yield data. Based on the results in Table 3 (coefficients, t-values, $p$ statistics) it can be stated that: (i) the daily growth of COVID-19 cases appeared to have a statistically significant negative effect on the market value of S\&P Green Bond Index; (ii) the daily growth of deaths caused by COVID-19 infection also appeared to have a negative impact; (iii) not surprisingly, the inverse statistically significant effect on yield of S\&P Green Bond Index was identified; (iv) market reaction to deaths proved to be stronger than the reaction to confirmed cases of COVID-19 infection. The results of this analysis is similar to the results obtained by Xing Yi et al. (2021), indicating the temporary increase of abnormal return in the green bond market. Moreover, these results also correspond to the results of similar researches on stock markets (for example, Quing et al. 2020; Zhang et al. 2020; Kanapickiene et al., 2020; Sansa 2020; Albulescu 2020), showing the negative impact of COVID-19.

In Phase 2 the effect of COVID-19 on the volatility is assessed using monthly data. As it can be seen from Figure 3, (i) the highest volatility of the S\&P Green Bond Index was observed in March, May, and July which partly coincides with the first wave of the COVID-19 pandemic (Appendixes A and B); (ii) after a sudden and significant increase in the first half of 2020, the volatility has demonstrated decreased and remained relatively low during the last months of the year 2020 .

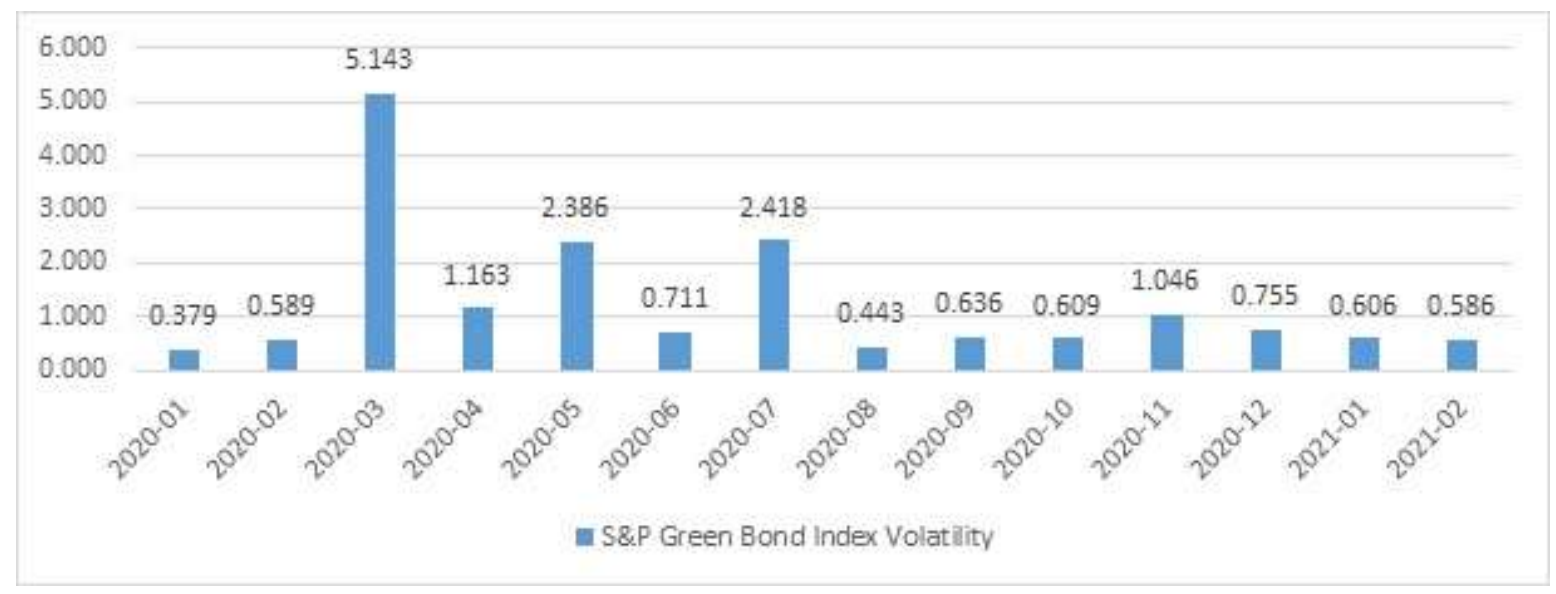

Figure 3. Monthly volatility of S\&P Green Bond Index

Source: authors calculations on the basis of S\&P Dow Jones Indices official database data.

Based on the results in Table 4 (coefficients, t-values, $p$ statistics) it can be stated that: (i) the monthly growth rate of COVID-19 cases reported proved to have a statistically significant positive impact on S\&P Green Bond Index volatility, i.e. the spread of the COVID-19 pandemic caused the increase of volatility, i.e. uncertainty, in the global green bond market. These results, indicating the increase of volatility in the green bond market in the face of the COVID-19 pandemic, corresponds to the results of previous studies (for example, Oxford Analytica, 2020; Sustainable Investing, 2020).

To summarize, it can be stated that the results of the research allow confirming Hypothesis 1, i.e. the spread of the COVID-19 pandemic has negatively affected the performance of S\&P Green Bond Index. The results also allow confirming Hypothesis 2, i.e. the spread of the COVID-19 pandemic has increased the volatility of S\&P Green Bond Index. Studies on the impact of the COVID-19 pandemic on the performance of stock markets (for example, Quing et al. 2020; Zhang et al. 2020; Kanapickiene et al., 2020; Sansa 2020; Albulescu 2020; Gormsen $\&$ Koijen 2020; Schoenfeld 2020 and others) provide similar results, i.e. shows the sudden but temporary negative effect on stock markets

It is very important to emphasize that this research was based on a relatively short data series. The analysis of the impact of the pandemic in a longer-term perspective (as soon as longer data series become available) and the analysis of the impact on regional green bond markets could be directions for further research.

\section{Conclusions}

The green bonds as an innovative financial instrument not only contribute to the prevention of climate change and the protection of the environment, but are also an important catalyst for sustainable economic growth, as well as provide numerous benefits to both issuers and investors. 
The global green bond market, having shown great success over the last decade, like other financial markets, has inevitably faced the consequences of the COVID-19 infection. However, in recent researches, this effect is evaluated only fragmentary.

The results of the research revealed a sudden negative shock on the global green bond market caused by the spread of the COVID-19 pandemic. However, after a sufficiently significant negative shift in terms of the market value, which was observed in the first quarter of 2020, the S\&P Green Bond Index regained its upward trend, which continued for the rest of the year. Yields to maturity rose sharply over the same period, reaching a record level of 2.15 percent in March 2020.

According to the results of the research, the spread of the COVID-19 pandemic appeared to have a negative impact on the performance of the S\&P Green Bond Index. The market reaction to deaths caused by COVID19 infection proved to be stronger than the reaction to confirmed cases of COVID-19 infection.

Finally, the results of the research have shown that the spread of the COVID-19 pandemic caused the increase of uncertainty in the global green bond market, but this increase was of temporary nature.

\section{References}

1. Alonso-Conde, A.B., Rojo-Suárez, J. (2020). On the Effect of Green Bonds on the Profitability and Credit Quality of Project Financing. Sustainability, 12, 6695. https://doi.org/10.3390/su12166695

2. Anh Tu, C., Sarker, T., Rasoulinezhad, E. (2020). Factors Influencing the Green Bond Market Expansion: Evidence from a Multi-Dimensional Analysis. Journal of Risk and Financial Management, 13, 126. https://doi.org/10.3390/jrfm13060126

3. Baker, M., Bergstresser, D., Serafeim, G., Wurgler, J. (2018). Financing the Response to Climate Change: The Pricing and Ownership of U.S. Green Bonds. NBER Working Paper, 25194. Retrieved from: https://ideas.repec.org/p/nbr/nberwo/25194.html

4. Banga, J. (2019) The green bond market: a potential source of climate finance for developing countries, Journal of Sustainable Finance \& Investment, 9(1), 17-32. https://doi.org/10.1080/20430795.2018.1498617

5. Bigger P. (2017). Measurement and the Circulation of Risk in Green Bonds. Journal of Environmental Investing, 8(1). Retrieved from: https://eprints.lancs.ac.uk/id/eprint/88690/

6. Cheong, C., Choi, J. (2020). Green bonds: a survey, Journal of Derivatives and Quantitative Studies: 28(4), 175-189. https://doi.org/10.1108/JDQS-09-2020-0024

7. Choi, J., Hoseinzade, S., Shin, S. S., \& Tehranian, H. (2020). Corporate bond mutual funds and asset fire sales. Journal of Financial Economics, 138(2), 432-457. https://doi.org/10.1016/j.jfineco.2020.05.006

8. Cochu, A., Glenting, C., Hogg, D., Georgiev, I., Skolina, J., Eisinger, F., Jespersen, M., Agster, R., Fawkes, S., Chowdhury, T., (2016). Study on the Potential of Green Bond Finance for Resource-Efficient Investments. Report of European Commission. Retrieved from: https://www.adelphi.de/en/publication/study-potential-greenbond-finance-resource-efficient-investments

9. Our World in Dara Coronavirus Pandemic (COVID-19) database. Retrieved from: https://ourworldindata.org/coronavirus

10. Deschryver, P., de Mariz, F. (2020). What Future for the Green Bond Market? How Can Policymakers, Companies, and Investors Unlock the Potential of the Green Bond Market? Journal of Risk and Financial Management, 13, 61. https://doi.org/10.3390/jrfm13030061

11. Flaherty, M., Gevorkyan, A., Radpour, S., Semmler, W. (2017). Financing climate policies through climate bonds - A three stage model and empirics. Research in International Business and Finance, 42: 468-479. Retrieved from: https://ideas.repec.org/a/eee/riibaf/v42y2017icp468-479.html

12. Flammer, C. (2013). Corporate Social Responsibility and Shareholder Reaction: The Environmental Awareness of Investors. Academy of Management Journal, 56(3), 758-781. Retrieved from: https://www.jstor.org/stable/43589942?seq=1

13. Gilchrist, D., Yu, J., Zhong, R. (2021). The Limits of Green Finance: A Survey of Literature in the Context of Green Bonds and Green Loans. Sustainability, 13, 478. https://doi.org/10.3390/su13020478 
14. Glomsrød, S., Wei, T. (2018). Business as unusual: The implications of fossil divestment and green bonds for financial flows, economic growth and energy market. Energy for Sustainable Development, 44, 1-10. Retrieved from: https://agris.fao.org/agris-search/search.do?recordID=US201800137211

15. Gormsen N.J., Koijen R.S. (2020). Coronavirus: Impact on Stock Prices and Growth Expectations. University of Chicago, Becker Friedman Institute for Economics Working Paper No. 2020-22. Retrieved from: https://bfi.uchicago.edu/working-paper/the-corona-virus-the-stock-markets-response-and-growthexpectations/

16. Hachenberg, B., Schiereck, D. (2018). Are green bonds priced differently from conventional bonds? Journal of Asset Management, 19, 371-383. https://doi.org/10.1057/s41260-018-0088-5

17. Harrison, C., Muething, L., Tukiainen, K. Green Bond Treasurer Survey, Climate Bonds Initiative, April 2020. Retrieved from: https://www.climatebonds.net/resources/press-releases/2020/04/green-bond-treasurersurvey-issuers-identify-multiple-benefits

18. Hjort, I. (2016). Potential climate risks in financial markets: A literature overview, Memorandum, No. 01/2016, University of Oslo, Department of Economics, Oslo. Retrieved from: http:/hdl.handle.net/10419/165944

19. Jansson, M., Biel, A. (2014), Investment Institutions' Beliefs About and Attitudes Toward Socially Responsible Investment (SRI): A Comparison Between SRI and Non-SRI Management. Sust. Dev., 22: 33-41. https://doi.org/10.1002/sd.523

20. Jun, M., Kaminker, C., Kidney, S., \& Pfaff, N. (2016). Green bonds: Country experiences, barriers and options. Input Paper In support of the G20 Green Finance Study Group. Retrieved from: https://scholar.google.com/scholar?cluster=1383257289114862004\&hl=en\&oi=scholarr

21. Kanapickiene, R., Teresiene, D., Budriene, D., Keliuotyte-Staniuleniene, G., Kartasova, J. (2020). The impact of COVID-19 on European Financial Markets and Economic Sentiment. Journal of International Scientific Publications, Economy \& Business, 14, 144-163. Retrieved from: https://ideas.repec.org/a/isp/journl/v14y2020i1p144-163.html

22. Kapraun, J., Scheins, Ch. (In)-Credibly Green: Which Bonds Trade at a Green Bond Premium? (March 5, 2019). Proceedings of Paris December 2019 Finance Meeting EUROFIDAI - ESSEC. http://dx.doi.org/10.2139/ssrn.3347337

23. Karpf, A., Mandel, A., (2018). The changing value of the 'green' label on the US municipal bond market. Nat. Clim. Chang, 8(2), 161-165. Retrieved from: https://hal.archives-ouvertes.fr/halshs-01905988/

24. King, M. 2017. The End of Alchemy: Money, Banking, and the Future of the Global Economy. 2nd ed. New York: W. W. Norton \& Company. Retrieved from: https://www.aeaweb.org/ econlit/jelCodes.php?view=jel

25. KPMG (2015). Gearing up for Green Bond. Key Considerations for Bond Issuers. KMPG International Sustainable Insight. Retrieved from: https://assets.kpmg/content/dam/kpmg/pdf/2015/03/gearing-up-for-greenbonds-v1.pdf

26. Lebelle, M.; Lajili Jarjir, S.; Sassi, S. (2020). Corporate Green Bond Issuances: An International Evidence. Journal of Risk and Financial Management, 13, 25. https://doi.org/10.3390/jrfm13020025

27. Liaw, K.T. (2020). Survey of Green Bond Pricing and Investment Performance. Journal of Risk and Financial Management, 13, 193. https://doi.org/10.3390/jrfm13090193

28. Ludvigsen, P. (2015) Advanced Topics in Green Bonds: Risks. Environmental Finance. Retrieved from: https://www.environmental-finance.com/content/analysis/advanced-topics-in-green-bonds-risks.html

29. Maltais, A., \& Nykvist, B. (2020) Understanding the role of green bonds in advancing sustainability, Journal of Sustainable Finance \& Investment. https://doi.org/10.1080/20430795.2020.1724864

30. Ng, A. W. (2018). From sustainability accounting to a green financing system: Institutional legitimacy and market heterogeneity in a global financial centre. Journal of Cleaner Production 195: 585-92. DOI: https://doi.org/10.1016/j.jclepro.2018.05.250

31. Otek Ntsama, U.Y., Yan, C., Nasiri, A. et al. (2021). Green bonds issuance: insights in low- and middleincome countries. Inernational Journal of Corporate Social Responsibility, 6(2). https://doi.org/10.1186/s40991$\underline{020-00056-0}$ 
32. Oxford Analytica (2020). Pandemic will weigh on green bond issuance this year. Retrieved from: https://dailybrief.oxan.com/Analysis/DB254764

33. Packer, F., Ehlers, T. (2017). Green Bond Finance and Certification. BIS Quarterly Review. Retrieved from: https://www.bis.org/publ/qtrpdf/r qt1709h.htm

34. Park, D., Park, J., Ryu, D. (2020). Volatility Spillovers between Equity and Green Bond Markets. Sustainability, 12, 3722. https://doi.org/10.3390/su12093722

35. Preclaw, R., Bakshi, A., (2015). The cost of being green. Barclays Capital Inc. Working paper. Retrieved from: https://www.environmental-finance.com/content/research/the-cost-of-being-green.html

36. Qing, H., Junyi, L., Sizhu, W., Jishuang, Y. (2020) The impact of COVID-19 on stock markets, Economic and Political Studies. Retrieved from: https://ideas.repec.org/a/taf/repsxx/v8y2020i3p275-288.html

37. Reboredo, J.C., (2018). Green bond and financial markets: Co-movement, diversifi- cation and price spillover effects. Energy Econ., 74, 38-50. Retrieved from: https://ideas.repec.org/a/eee/eneeco/ v74y2018icp3850.html

38. S\&P Dow Jones Indices (2021). https://www.spglobal.com/spdji/en/indices/esg/sp-green-bondindex/\#overview

39. Sansa, N. A. (2020). The Impact of the COVID-19 on the Financial Markets: Evidence from China and USA. Electronic Research Journal of Social Sciences and Humanities, 2(2), 29-39. http://dx.doi.org/10.2139/ssrn.3567901Albulescu 2020

40. Schoenfeld J. (2020). The invisible risk: Pandemics and the financial markets. Covid Economics, Vetted and Real-Time Papers, 6, 119-136. https://voxeu.org/article/invisible-business-risk-covid-19-pandemic

41. Sustainable Bonds Insight (2021). Environmental finance. Retrieved from: https://www.environmentalfinance.com/assets/files/research/sustainable-bonds-insight-2021.pdf

42. Sustainable Investing (2020). Research Note: Coronavirus Pandemic Impact on Green Bonds. Retrieved from: https://www.sustainableinvest.com/coronavirus-impact-on-green-bonds/\#_ftn1

43. Tolliver, C., Keeley, A. R., Managi, Sh. (2019). Green bonds for the Paris agreement and sustainable development goals. Environmental Research Letters, 14, 064009. https://doi.org/10.1088/1748-9326/ab1118

44. Tuhkanen, H., Vulturius, G. (2020) Are green bonds funding the transition? Investigating the link between companies' climate targets and green debt financing. Journal of Sustainable Finance \& Investment, 1-23. https://doi.org/10.1080/20430795.2020.1857634

45. Upbin, B., Hackel, Ch., Harman, S., Hishikava, L., Kuh, T., Briand, R. (2014). Barclays MSCI Green Bond Indices Bringing clarity to the green bond market through benchmark indices. Retrieved from: https://www.investmentbank.barclays.com/content/dam/barclaysmicrosites/ibpublic/documents/investmentbank/global-insights/green-bond-benchmark-indices-bringing-clarity-to-the-green-bond-market-696kb.pdf

46. Wanke, S. 2017. Oil Prices and Bond Yields Hand in Hand Again. KfW Research 47. July. Retrieved from: https://www.kfw.de/PDF/Download-Center/Konzernthemen/Research/PDF-Dokumente-Volkswirtsch aftKompakt/One-Pager-2017-EN/VK-No.-140-July-2017-Oil-prices-and-bond-yields.pdf

47. Xing Yi, Caiquan Bai, Siyuan Lyu, Lu Dai (2021). The impacts of the COVID-19 pandemic on China's green bond market. Finance Research Letters, 2021, 101948. https://doi.org/10.1016/j.frl.2021.101948

48. Zerbib, O. D. (2019). The effect of pro-environmental preferences on bond prices: Evidence from green bonds. Journal of Banking \& Finance, Elsevier, 98(C), 39-60. https://doi.org/10.1016/j.jbankfin.2018.10.012

49. Zhang, D., Hu, M., Ji, Q. (2020). Financial markets under the global pandemic of COVID-19. Elsevier Finance Research Letters. https://doi.org/10.1016/j.frl.2020.101528

50. Zhou, X., Cui, Y. (2019). Green Bonds, Corporate Performance, and Corporate Social Responsibility. Sustainability 11, 6881. https://doi.org/10.3390/su11236881 
Appendix A. Daily growth rate of COVID-19 infections (cases)

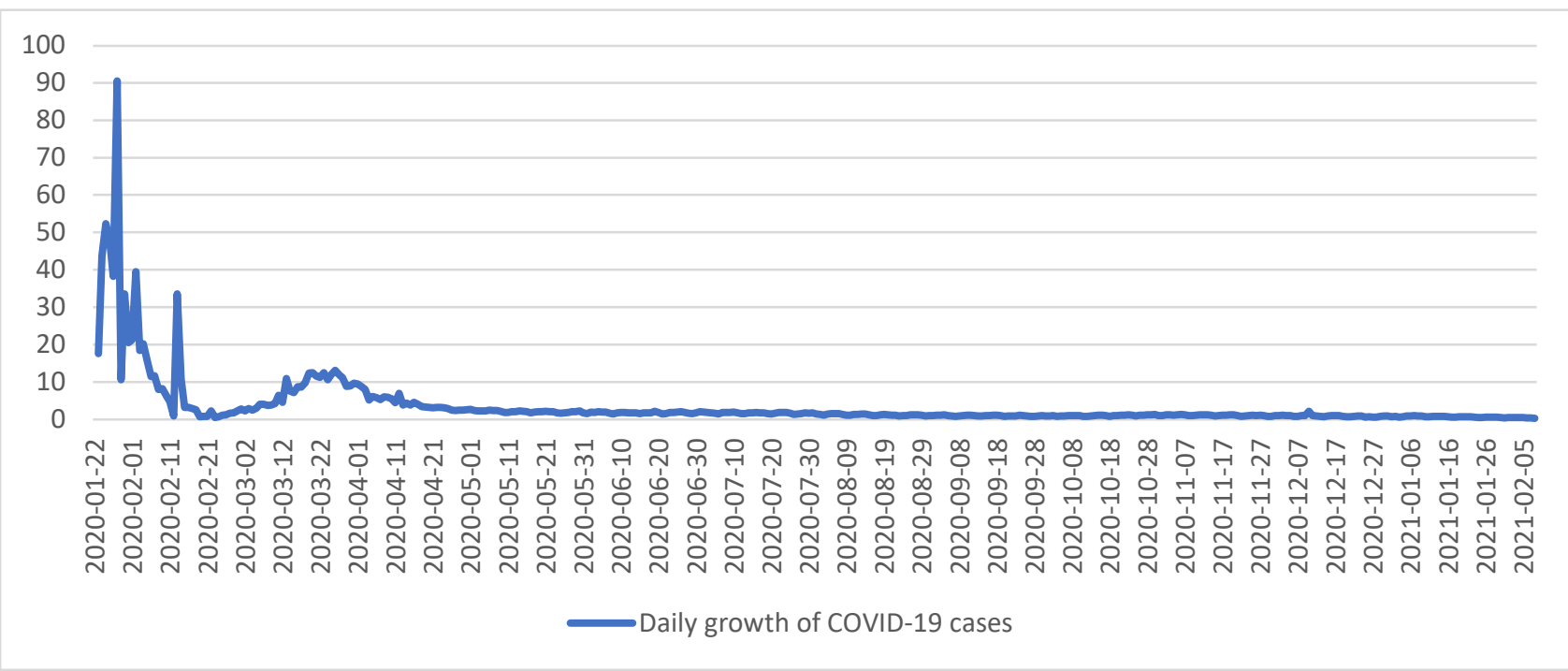

Source: compiled by authors calculations on the basis Our World in Data Coronavirus Pandemic data.

Appendix B. Daily growth rate of deaths caused by COVID-19 infection

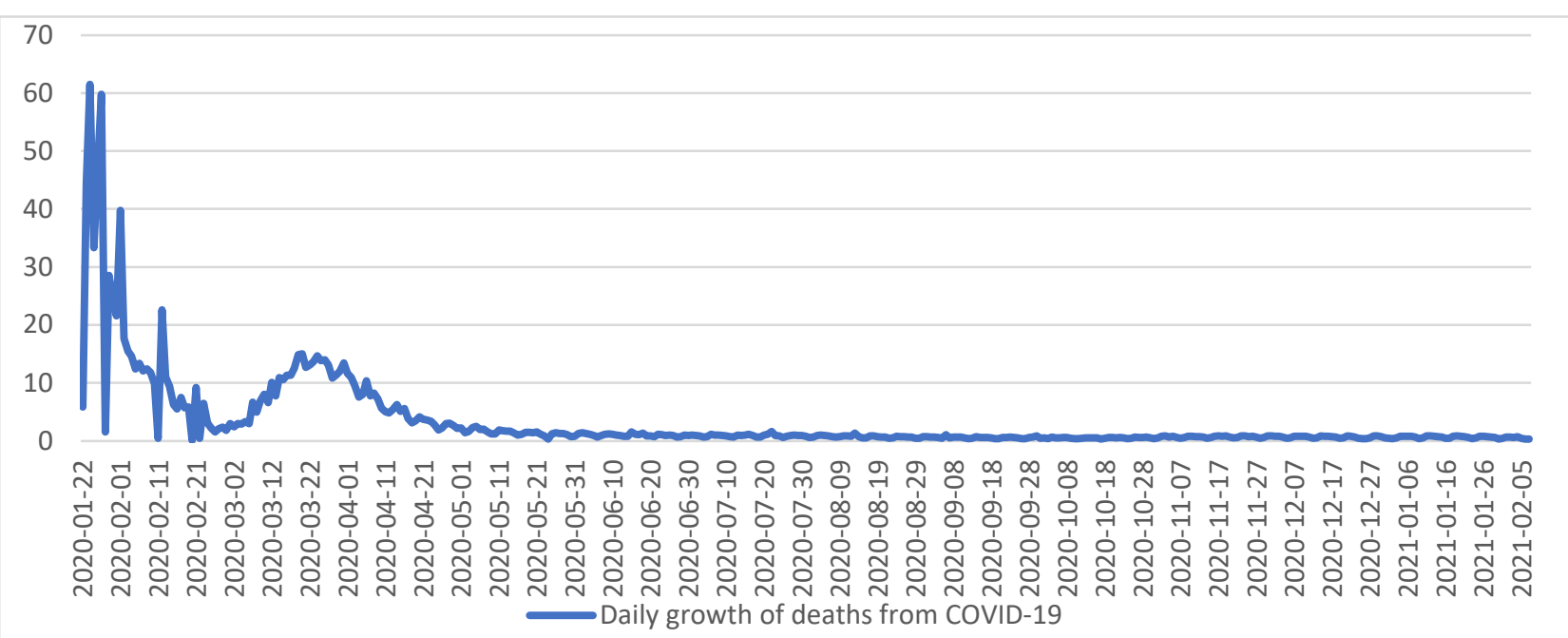

Source: compiled by authors calculations on the basis Our World in Data Coronavirus Pandemic data.

Appendix C. Short-term dynamics of S\&P Green Bond Index (Yield to Maturity)

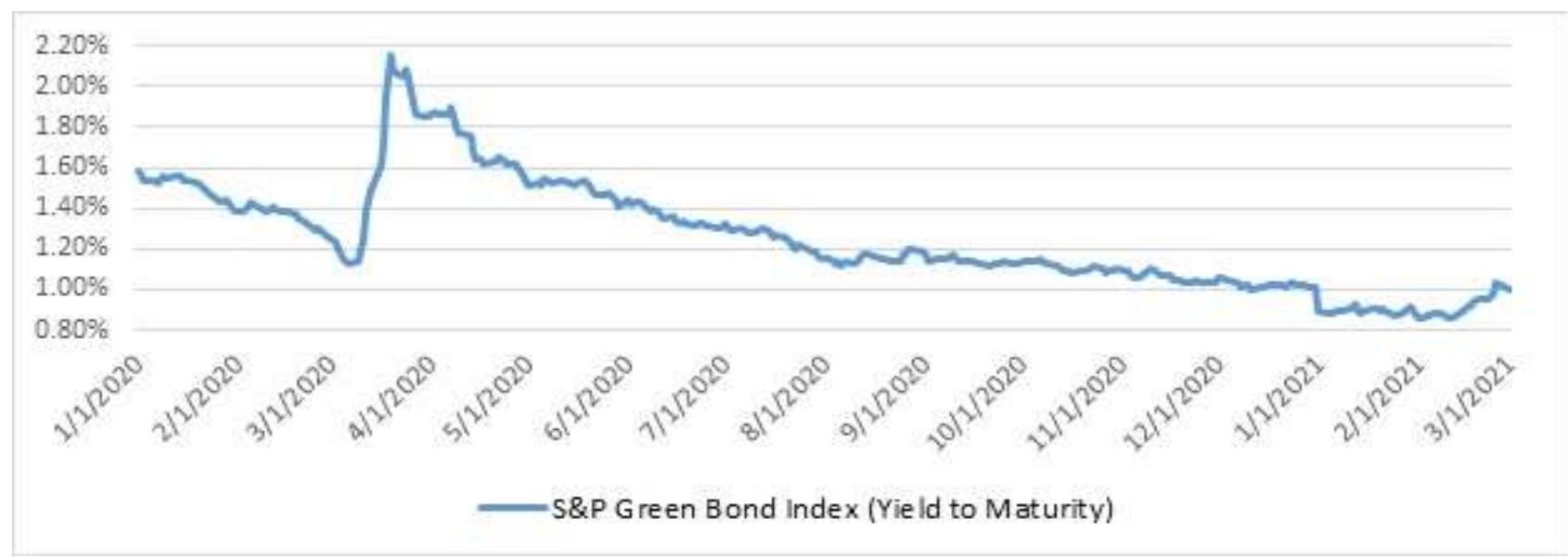

Source: compiled by authors on the basis of S\&P Dow Jones Indices official database data. 